Original Article

http://dx.doi.org/10.1590/0104-07072014000930013

\title{
INFORMATION FOR THE OPTION OF PLANNED HOME BIRTH: WOMEN'S RIGHT TO CHOOSE ${ }^{1}$
}

\author{
Heloisa Ferreira Lessa', Maria Antonieta Rubio Tyrrell ${ }^{3}$, Valdecyr Herdy Alves ${ }^{4}$, Diego Pereira Rodrigues ${ }^{5}$
}

${ }^{1}$ Results of the thesis - Women's health and the option for planned home birth, presented to the Postgraduate Program in Nursing, at the Anna Nery School of Nursing (EEAN), Universidade Federal do Rio de Janeiro (UFRJ), in 2012.

${ }^{2}$ Ph.D. in Nursing. Coordinator of the Ecological Birth Multi-professional Team for Attendance to Planned Home Births. Professor of the Ecology of Labor and Childbirth held in partnership with the Primal Health Research Center. Rio de Janeiro, Rio de Janeiro, Brazil. Email: heloisa.lessa@terra.com.br

${ }^{3}$ Ph.D. in Nursing. Full Professor of the EEAN/UFR. Rio de Janeiro, Rio de Janeiro, Brazil. Email: tyrrell2004@hotmail.com

${ }^{4}$ Ph.D. in Nursing. Full Professor of the Aurora de Afonso Costa School of Nursing (EEAAC) of Universidade Federal Fluminense (UFF). Rio de Janeiro, Rio de Janeiro, Brazil. Email: herdyalves@yahoo.com.br

${ }^{5}$ Undertaking M.Sc in Health Care Sciences, EEAAC/UFF. Rio de Janeiro, Rio de Janeiro, Rio de Janeiro, Brazil. E-mail: diego. pereira.rodrigues@gmail.com

\begin{abstract}
This article is part of an investigation which used the institutional ethnography of Dorothy Smith, aiming to describe women's process of choice in planned home birth. It used interviews held with 17 women who gave birth at home between 2008 and 2010 in Rio de Janeiro. We selected one category: information - a step for the option for planned home birth. The category was constructed based on six subcategories: knowing persons who had a home birth; knowing persons with negative experiences; the Internet as a source of information; books as a source of information, information from health professionals; and, the exchanging of information between women. The information acts as a network of knowledge, reports and experiences in their symbolic dimensions, favoring the raising of consciousness and the social organization of support. These knowledges and practices are a foundation for a social understanding and the women's discourse in the option for planned home birth.
\end{abstract}

DESCRIPTORS: Health policy. Normal birth. Information. Obstetric nursing.

\section{INFORMAÇÃO PARA A OPÇÃO PELO PARTO DOMICILIAR PLANEJADO: UM DIREITO DE ESCOLHA DAS MULHERES}

\begin{abstract}
RESUMO: Este artigo é parte de investigação que utilizou a etnografia institucional segundo Dorothy Smith, com o objetivo de descrever o processo de opção das mulheres pelo parto domiciliar planejado. Utilizou-se entrevista com 17 mulheres que pariram no domicílio entre 2008 e 2010 no Rio de Janeiro. Selecionamos uma categoria: informação - um passo para a opção pelo parto domiciliar planejado. Categoria construída a partir de seis subcategorias: conhecia pessoas que tiveram parto domiciliar; conhecia pessoas com experiências negativas; internet como fonte de informação; livros como fonte de informação, informações a partir de profissional de saúde; e troca de informações entre mulheres. A informação atua como rede de conhecimento, relatos e experiências em suas dimensões simbólicas, favorecendo a conscientização e organização social de apoio. Esses saberes e práticas são alicerces de uma compreensão social e discurso próprio da mulher na opção pelo parto domiciliar planejado.
\end{abstract}

DESCRITORES: Política de saúde. Parto normal. Informação. Enfermagem obstétrica.

\section{INFORMACIÓN PARA LA OPCIÓN POR EL PARTO DOMICILIARIO PLANEADO: UN DERECHO DE ELECCIÓN DE LAS MUJERES}

\begin{abstract}
RESUMEN: Este artículo forma parte de la investigación que ha utilizado la etnografía institucional según Dorothy Smith, cuyo objetivo ha sido describir el proceso de opción de las mujeres por el parto domiciliario. Se ha utilizado una entrevista con 17 mujeres que dieron a luz en sus hogares entre 2008 y 2010, en Rio de Janeiro. Seleccionamos una categoría: información - un paso para la opción por el parto domiciliario planeado. Categoría construida a partir de seis subcategorias: conocía a personas que habían tenido su hijo por parto domiciliario, conocía a personas con experiencias negativas, internet como fuente de información , libros como fuente de información, informaciones a partir de profesional de salud, intercambio de informaciones entre mujeres. La información actúa como red de conocimiento, relatos y experiencias en sus dimensiones simbólicas, favoreciendo la concientización y organización social de apoyo. Esos saberes y prácticas son la base de una comprensión social y discurso propio de la mujer en la opción por el parto domiciliario planeado. DESCRIPTORES: Política de salud. Parto normal. Información. Enfermería obstetricia.
\end{abstract}




\section{INTRODUCTION}

The present study focusses on women's option for planned home birth in major urban centers. It is an issue of interest due to the growing demand resulting from social movements, the World Health Organization (WHO), and from organized sectors of society, which culminated in public policies favoring the work of obstetric nurses, obstetricians, and doctors in attending planned home birth in urban centers, in spite of the marginal position in which the same find themselves in our society. ${ }^{1}$

According to the Brazilian Ministry of Health, $90 \%$ of births in Brazil occur in the hospital environment. The quantitatively-broadened access to prenatal services and to the health services for assistance with birth, in the majority of cases, has translated into a care based on the medicalized model of care, in which the use of interventions such as the administration of oxytocin, the undertaking of episiotomies, breaking of the waters and unnecessary cesareans continue to be frequent. This issue predominates in the hospital context where the paradigm is technocratic in relation to the obstetric care, which translates into a high number of cesareans, a fact confirmed in the data on the Live Births Information System (SINASC, in Portuguese), which evidences that in 2010, the percentage of cesareans in Brazil was $52 \%$, reaching $58 \%$ in the State of Rio de Janeiro in $2009 .{ }^{2}$

In this line of thinking, in 2009, the prevalence of births in the Municipality of Rio de Janeiro which were assisted in health establishments was $99.76 \%$; ${ }^{3}$ currently, the only option for non-hospital birth within the Unified Health System (SUS) is the Casa de Parto David Capistrano Filho, located in the Realengo neighborhood, linked to the Municipal Health Department of Rio de Janeiro.

The idea which is current in Brazilian society, even shared by health professionals, is that home birth, even when planned, represents a higher risk of unfavorable maternal and neonatal outcomes. However, scientific evidence reports that planned home birth for women of low obstetric risk is as safe as normal hospital birth, and should be offered as an option for healthy women who wish for it. ${ }^{4-7}$

In our society, generally speaking, women live immersed in a culture which is pro-cesarean and which denies their condition of citizen, in which the inexistence of the possibility of the option relating to place of birth causes neither fright nor anger. However, in the last 10 years, a significant expansion has occurred in women's' and health professionals' movements, which have sought to discuss alternatives to the predominant model of health care in Brazil. ${ }^{8}$ The popularization of the Internet has contributed to the growth of this form of social expression, making it possible for service users to find information on modalities of birth which are different from the technocratic hospital model.

In this study, learning with the diversity of the information in the informed option or choice for planned home birth, the term "option" occurred following the clarification of the meaning of the words "option" and "choice". Turning first of all to the Dicionário da Lingua Portuguesa (Dictionary of the Portuguese Language) for the etymological clarification of these terms, it was observed that "option" is the act, right or competence to opt, preference and free choice; and that "choice" refers to the act or effect of choosing, option, preference, selection. ${ }^{9}$

It seemed more appropriate to us to adopt the term 'option', bearing in mind that its conceptual connotation encompasses, on one hand, the capacity for free choice, and on the other hand, the condition of the woman's citizenship, and recognizing the right as a mark of power and autonomy in relation to the decision for planned birth.

In the search for the meaning - in the English language - of the term 'option', when linked to the issue of home birth, one finds within its description and analysis the issue of informed choice, which in Portuguese is "opção informada" which, according to the College of Midwives of Ontario (Canada), is a process of option which depends on a complete exchange of information, in a non-emergency and non-authoritarian manner. ${ }^{2}$

In this conceptual context, informed choice can be understood as an ideological principle which guides the interaction between the woman and the professional midwife. In Brazil, the professional midwives are the obstetricians and obstetric nurses. This being the case, the midwife must inform the woman about the scientific evidence in the process of care required. ${ }^{6}$

Informed choices based on feminist rhetoric are a concept in the reconfiguration of the relationship between the client who is cared for and the caregiver, this concept being considered the "heart" of the feminist movements, as they constitute a more egalitarian relationship in the decisions made by the woman in relation to her own body. ${ }^{10}$

Based on access to the information and a consequent full awareness of the rights of citizenship, empowerment is related to the exercising of control of our acts. It is this that promotes the change of passive attitudes to active stances, allowing the individual to be able to know what is best for herself. ${ }^{11}$ 
In the light of the above, the intention is to offer support for new health policies which may effectively ensure women greater access to information regarding their rights in relation to labor and childbirth, whether the event is undertaken in the hospital ambit, in the normal birth centers, or at home, so long as it occurs through the woman's free choice.

It should be noted that the study's theoretical assumption was the existence of factors which influence the process of choice for planned home birth, as an expression of the right to citizenship and autonomy. The investigation's objective was to describe the women's process of choice for planned home birth.

\section{METHOD}

This study's methodological option resulted in an institutional ethnographic study, as it considers its link to the cultural context and to human behavior in an approach of the feminist movement. Thus, it is possible to produce a photograph and describe the social context of the place where the subject or subjects involved in the investigation are found. In this type of study, one seeks to acquire knowledges regarding how the different social groups function; ${ }^{12}$ the qualitative focus, in its turn, allows the deepening of the information in the world of the meanings and the human relationships. ${ }^{13}$

The ethnographic study creates contextual, holistic and reflexive theories or conceptions, without testing predetermined hypotheses. Ethnography believes that the social world must be studied fundamentally in its locus; because of this, the choice was made to interview the women in their homes, a place defined by them.

Institutional Ethnography is an empirical research approach; it is linked to the rules and to the social organization of a specified fact or event. It proposes a sociology which is based on peoples' experience, and not a theory. It combines theory and method, and focuses on the connections between places and situations of daily life or professional practice. This method was created by Dorothy Smith, a sociologist who was strongly influenced by feminism, who thought about the knowledge deriving from the practice, and how the same returns to it. ${ }^{14}$ The author asserts that, by seeing from the woman's point of view, based in her routine activities, it is possible to go beyond the dominant practices, and speak of women with accuracy. ${ }^{15}$

For the theorist, ${ }^{16}$ Institutional Ethnography is a method for exploration and discovery of obscure or unknown issues; it is, therefore, appropriate to the study of the issue of informed choice for planned home birth in urban centers.
The selection of the interviewees took place based on the search for information on professionals who accompany home births in the city of Rio de Janeiro, namely: four obstetric nurses and two doctors. These professionals were informed about the research by telephone, when they were asked to provide contact details for clients who had actually given birth at home, in the period January 2008 - December 2010. The immediacy with which the professionals provided the information requested was noteworthy, producing a survey of 65 women, 40 of whom were attended by this study's researcher. Among the remaining 25 women, it was possible to locate and interview 11.

Nevertheless, the qualification commission for the study's preliminary report recommended the inclusion of the number of women attended by the researcher, so as to achieve data saturation. Moving forward on this basis, the selection of these interviewees occurred based on random sampling among the 40 who had not initially been considered as part of the population. Among the 10 women chosen, we interviewed only six, due to recognition of data saturation. As a result, the final sample was made up of 17 women who had experienced a planned home birth, after they had agreed to participate in the study, and to the terms of consent, as stipulated in Resolution CNS-196/96, ensuring anonymity and the confidentiality of the information through the use of an alpha-numeric code $\left(\mathrm{E}_{1} \ldots \mathrm{E}_{17}\right)$.

Data collection was undertaken in the first semester of 2011 through semi-structured interviews which were digitally recorded, with the interviewees' prior authorization, and transcribed by the researcher. Prior to beginning the recording, the interviewees responded to questions referent to their respective characterization. After this stage, they were asked to report how they opted for a planned home birth. The women spoke freely. When it was necessary to obtain information not addressed by the interviewees, the researcher made use of keywords found in the script to achieve the study's objectives. In addition, notes were made in a fieldwork notebook as a stage of data collection. Following the transcription of the accounts, the reports were validated by the interviewees, thus allowing the undertaking of the analysis of the material's content.

In order to analyze the data collected, we chose the thematic categorization resulting from the interviews. ${ }^{12}$ Following the transcription of the interviews, we used the record unit based on the theme as a strategy for organizing. We used colors for identifying each record unit and grouped the similar record units, allowing a general view of the issue. The interviews gave rise to 45 record 
units based on the thematic grouping, which, in its turn, was the basis for the construction of nine subcategories, namely: learning from a variety of information; the relationship with the baby's father; the relationship with the family and the friends; home birth, positive and negative aspects; the relationship with the health system and the doctor; the relationship with the professional; stories which marked her trajectory; a different way of facing my body, life, and the world; and, reactions following birth.

Three major categories emerged from the nine subcategories: information - a step for the option for planned home birth; influence in the option for planned home birth; and, the option for the natural birth and de-medicalization.

The category presented here is information a step for the option for planned home birth, which was constructed based on two subcategories, namely: learning from a variety of information; and the relationship with the baby's father. Learning from a variety of information emerges based on seven record units, namely: knowing persons who had a home birth; knowing persons with negative experiences; the Internet as a source of information; books as a source of information, information from other health professionals; and the exchanging of information with other women and comparison with other countries. The subcategory: the relationship with the baby's father originated from three record units: the father in relation to home birth, negotiating the participation of the father with the hospital, and the participation of the father in the birth process.

It is important to emphasize that the investigation was undertaken following consideration by the Research Ethics Committee of the Anna Nery School of Nursing, of the Federal University of Rio de Janeiro, regarding its ethical and legal aspects, and was approved under protocol n. 078/2010.

\section{RESULTS AND DISCUSSION}

The characterization of the interviewees was as follows: 13 were primiparous; at the time of the birth they were aged between 21 and 41 years old. In relation to place of residence, there was prevalence of those who lived in regions with a higher socioeconomic level, indicating the possible influence of financial factors in the choice of the place of birth. All had university degrees and daily access to the Internet, meaning that qualified and diversified information emerges as key to the informed choice. Studies undertaken in England and in São Paulo with women who gave birth at home found results similar to this. ${ }^{1,17}$ It was also observed that the majority of the women contributed considerably to their family's incomes.

\section{Information: a step for the option for planned home birth}

All the women reported seeking and accessing information as an important part of the choosing process. None of them stated that they had made this choice from one hour to the next; on the contrary, they reported that they experienced an internal and external process in the social relationships, until they arrived at the choice, thus confirming that the final option is the result of information from different sources that has two basic pillars: safety for the mother and baby, and the de-medicalization of the process of parturition and childbirth, as stated in the following account:

[...] there was nothing which clicked, from one hour to the next. I built up what I knew, I had doubts, I looked things up, I asked questions [...] $\left(\mathrm{E}_{3}\right)$.

The access to diversified information is owed mainly to these women's educational condition, and appears as an influential factor in their becoming aware and in the choice for a planned home birth. This fact, as it was reported by the women, represented the first step for the determination of the option made. In this study, the diversified information was termed as such because it originated in sources which were differentiated based on the women's social relationships, whether they had or not undertaken or assisted in a home birth, and were limited to the different means of communication.

The information acts as the conductor of a network of knowledges and accounts of experience in two dimensions: internal and external. The first serves as a base for the process of consciousness-raising, and the second, for the establishment of a social support organization. In this, the knowledges and the practices are the basis of a social understanding as a discourse of the woman and not for the woman. ${ }^{18}$

In looking at how our society is organized on the issue of labor and childbirth, it may be ascertained that the women assert that they actively need to seek differentiated information in order to reach the point where they opt for home birth. This occurs because the social relationships in Brazil confirmed the hospital as the only place of birth. $8,19,20$

Media campaigns reinforce the importance of the medical professional during pregnancy and birth. The power relationships are clear, and the women participate in this social relationship with the professional. The women's participation in the process, even though limited, confirms the 
literature ${ }^{16}$ in the sense that the social relationships do not occur for the persons, and are not made for the persons. The persons actively constitute the social relationships. ${ }^{15}$ This being the case, in the majority of occasions, the women delegate the power to the professional or simply accept his knowledge as unquestionable, due to not having access to data which allow them to question the specialists' scientific knowledge. The search for information, on its own, may be recognized as a new power relationship which is established between professionals and clients. ${ }^{16}$

Whether they are primiparous or not does not change the fact. These women mention - at some point of their process - the access to differentiated information as support for their choice, as the report below emphasizes:

[...] well, I began to gather information on the issue, on the humanization of the birth, on the options, and began to get pretty interested in home birth, but wasn't able to go ahead with this in my first pregnancy. It ended up being a hospital birth which was not much how I had hoped, which led me to seek a home birth with greater dedication in my second pregnancy $[\ldots]\left(\mathrm{E}_{12}\right)$.

This account shows that this woman's change of attitude - in this case, the search for another professional who would be appropriate for her needs - did not occur easily or spontaneously. It was the fact of having an expectation frustrated which drove her to seek information and professionals who would allow her to experience a new power relationship, with new rules of social organization, in which her wishes could be respected, including in the issue of the choice of place of birth.

The women also indicated that access to information has different origins: they can be direct (person/person), occur in pregnancy groups, or originate from varying means of communication. It was clear, furthermore, that the information can have a scientific origin or be the result of experience.

\section{Knowing people who had a home birth}

The data demonstrate a predominance of women who knew somebody who had had the experience of a home birth, as shown in the accounts below:

[...] I opted for this because, first of all, I knew people who had given birth at home $[. .].\left(\mathrm{E}_{1}\right)$.

[...] nowadays, it is a more normal path. I know various people who had their babies at home $[\ldots]\left(\mathrm{E}_{6}\right)$.

The majority of women in the city of Rio de Janeiro does not imagine the possibility of a birth outside hospital; this is because this information is not available in the health services; and, in their turn, they do not seek this information. In the texts and forms to which the women have access, such as the pregnancy care-planning card, reference is not made to the possibility of an option relating to the place, or to the professional who assists with the birth in the public or private health services, which supports the premise of Dorothy Smith ${ }^{16}$ that the texts are mediators and organizers of the social relationships.

At no point did the interviewees report having received any information about the possibility of choice, neither in regard to the place of birth or any other item; indeed, very much to the contrary, they reported that there was an information gap when they were attended in the hospital. The search for the information led them, in practice, to the possibility of the choice, a choice which is not available for the population in general, as the Unified Health System (SUS) does not offer this mode of care.

The search for the information, even prior to the choice, including in the cases in which the final choice was not for home birth, clearly shows an internal recognition, a different way of seeing the world and the relationships around one, as the excerpt of the account below shows:

[...] after I spoke with a friend who had given birth at home, I became more keen, because in the beginning I was a bit afraid [...] $\left(\mathrm{E}_{14}\right)$.

In this case, it was the information that was responsible for reducing the fear, as one interviewee recognized:

as soon as I fell pregnant, I had friends around me who had already made this choice. For me, this was a natural thing, it was already part of conversations with other pregnant women. And I thought that it was the best option $[\ldots]\left(\mathrm{E}_{17}\right)$.

Based on the accounts, it was observed that the women who gave birth at home contributed decisively to the choice made by other women, through the exchanging of knowledges and practices related to the choice for home birth. The experience confers the condition of authority and decision on these women. On the issues of giving birth and the choice of the place of birth, the women themselves see themselves as holders of knowledge arising from the practice of friends who experienced home birth. The way the women recognize the knowledge as arising from the experience of giving birth is part of the power relationships which surround these women's relationships and their choice of home birth.

What could be a subgroup of women appears: those who experienced birth outside of the hospital institution. This sharing of ideas which is created in the relationships between women with 
similar experiences is a fact which supports, in this case, the choice of home birth. ${ }^{18}$

\section{Knowing persons with negative experiences}

It was also noted that among the women, some stated that previous negative experiences in hospital - their own or of third parties - were important in the decision. Once more, the knowledge has its origin in practice, which authorizes and legitimates the account below:

[...] but, once you start getting accustomed to an environment, let's say, that of finding stuff out, an environment of people who have already gone through this experience of talking with people who know what this is like, and people who also went through the opposite, through the opposite of having a child in a strange place [...] $\left(\mathrm{E}_{1}\right)$.

The positive experience and the access to information appear as encouragement, in contrast to the difficulty of the other women's experience, based on the environment when they gave birth. The environment is not limited only to its physical aspect, as it is there that the professionals are found. The most determinant aspect is not regarding the physiological processes, but rather the strange/unknown place. The "strange place", here determines a social relationship which meets other needs apart from those of the women in the process of giving birth, causing them to feel excluded from a process which is theirs by nature, by legitimacy and by right. On this subject, an excerpt from one account follows:

[...] so I went to the maternity center, and went through all that process of taking my clothes off, of dry shaving. I can remember the sound of the blade on my skin. And all of this during labor, so it was very traumatizing for me [...] $\left(\mathrm{E}_{4}\right)$.

The previous negative experience, when pregnant, or of somebody who they personally know, exercises a powerful influence in the search for a choice which respects their needs for care that is not standardized and which is determinant of their own social relationship. The process of (de) characterization described above, the failure of professionals to recognize their needs and the difficulties they face in the experience of birth, make the experience of giving birth absolutely negative.

\section{The Internet as a source of information}

The women confirmed that they accessed the Internet in order to obtain information about natural birth, as we can see in the account below:

[...] I went on the Internet... You know, the Internet gave me a lot of support regarding the doubts that my friend had given me, because her opinion was still very exaggerated, she was experiencing this. But then the Internet gave me more support, through watching doctors speaking, through seeing people, a network, and seeing how widespread this was, the extent to which it wasn't just my friend going crazy [...] $\left(\mathrm{E}_{2}\right)$.

The Internet and globalization appear as a striking factor in accessing information, and have become determinant. Some authors indicate that the web has not reached its maximum peak in the sense of offering health information, as is the also the case with social media and its Groups. ${ }^{2}$

One can perceive that, currently, the Internet confirms the friend's experience, demonstrating that this is not something exceptional, personal or occasional; and that there is a chain, other professionals involved, a respectable attitude. In the account, one can observe the construction of the interviewee's choice, in which the identification with the friend and the discovery, based on the other's experience, are fundamental. The information obtained on the Internet reinforces the experience/practice of women in the social network. Through Institutional Ethnography, the power relationships which appear based on the routine experience were revealed, as ascertained in this study. It can be deduced how the experience, in this case, confers authority and legitimacy: ${ }^{8}$

[...] I was very lonely at home, so I began to chat on the Internet [...] $\left(\mathrm{E}_{2}\right)$.

In the last 10 years, the Internet has become a source of health information, and it is women who access it most for this purpose. ${ }^{21}$ On the Internet, the person undertakes an active search, interacts in the process, and accesses all types of information: those with scientific characteristics and also those of low quality, often including erroneous information. One can question the scientific quality of the information received and, for this, more specific studies are necessary, assessing the information accessed; furthermore, it may be inferred that these women access the Internet aiming to research, clarify doubts, obtain support for their decision/ reflection, eliminate unknown facts, correct possible stigmas and exclusions, and construct social support networks. ${ }^{22}$

\section{Books as a source of information}

Also in relation to information, some women indicated books as a source, even mentioning the author and obstetrician Michel Odent, who has participated in several events in Brazil since 2000. The importance in Brazil of the presence of this and other national and international icons in this issue is reinforced by the accounts which followed: 
[...] I also saw some books by Michel Odent, I found out about him, I saw other books [...] $\left(\mathrm{E}_{14}\right)$.

[...] in the beginning, my mother was very scared, so afterwards I took her Michel Odent's book [...] and she really liked it $[\ldots]\left(\mathrm{E}_{7}\right)$.

Reading, and new scientific concepts appear as a source of security. What these accounts show is the possibility of a change of behavior based on access to information made available in books. The social relationships are influenced by and mediated by texts. The books bring new concepts which change the social relationships between women, professionals and health institutions. ${ }^{16}$ The interviewees indicated the need to carry out an active search in order to have access to the specialized scientific literature. The information identified here served as a basis for changing the social relationships and the power relations which impose the traditional hospital birth or scheduled cesareans upon the women.

\section{Information from the health professionals}

Women were identified who received positive information relating to planned home birth from professionals apart from those responsible for the prenatal consultations, as in the case below:

[...] I met a psychologist in the maternity center, and said that I wanted to have my baby at home, but that I didn't have the money... And she told me, off the record, 'if you want to have your baby at home, the first thing I'll tell you is: go and look for the people... Sincerely, this is a much healthier option, much more pleasant than having your child here'. My jaw dropped!! 'But if you need it, the hospital is here. You can carry on with your prenatal consultations'.

The professional of the institution makes it clear to the woman that it is easier to achieve her wish in direct negotiations with an autonomous professional, outside the hospital, than to try to flexibilize rules in a hospital institution. The person who holds the power, who gives support, is the same person who reinforces the woman's wish and drives her audacity in the search for a choice:

[...] I found out about home birth. Actually, it was my husband who told me that it existed, and the person who told him was his therapist $[. .].\left(\mathrm{E}_{10}\right)$.

The professionals - both autonomous or linked to the health institutions - in this case recognized and encouraged the choice for the planned home birth. We are, therefore, speaking about an absolutely selected group of professionals who showed that they sought scientific evidence upon which to base their practice, which we understand as a reason for optimism.

\section{The exchanging of information between the women}

To talk about information means to talk about something material, such as statistical data, for example. Here, we are talking about an activity to be undertaken based on scientific evidence. The women, however, bring new meaning to the information, as shown in the account below:

[...] through a friend who went through the experience of a home birth, which I followed from the beginning of the pregnancy [...]. Then, when her baby was born and I went to visit, she was so radiant, splendid, magnificent, and when she told me about how her birth had been, I thought: God, what light there is in this house, this child, this friend of mine [...] $\left(\mathrm{E}_{2}\right)$.

The first step is to recognize the authority of those who live through this experience - in this case, the home birth - shortly after the recognition, in this experience, of a result which goes beyond a healthy mother and baby. We are talking of well-being, integrity, a feeling of power, recognition of her real strengths purely through the fact of being a woman. Through the interviewees' discourses, one can understand the greater meaning of the possibility of a more pleasurable experience of birth, which clearly does not occur frequently in our society. ${ }^{1}$ The recognition of this power, inherent to the female sex, in the strictest sense of the word, makes all the women who opted for this path equal. The exchanging of experiences between the women is presented, therefore, as an important source of information, which facilitates the choice of a planned home birth.

\section{FINAL COMMENTS}

The process of opting for the planned home birth, in major urban centers, begins based in access to information, whose origin may be individual or occur in personal contact, or in social networks on the Internet, considered diversified and qualified information, based in the experience of other women, an empirical knowledge, and also scientific knowledge. The women exchange knowledges and practices, making the home birth an option constructed over the duration of the pregnancy.

In this process, the women establish social relationships and use these as a base in the interactions with partner, family, and friends: social relationships constructed based on women who are informed and financially independent, who (de)construct the gender relations based on the difference of sexes. They construct strategies for strengthening relationships, with greater equality of rights. Through the awareness of their physi- 
ological possibilities as women, they empower themselves and build the relationship with the health professional, and in this way maximize the potential for a personal and political stance which consolidates their choice and decision.

The concepts of Dorothy Smith and her theoretical framework validated the raising of awareness and strengthened the defense of the women's social movements, and of the search for the closing of gaps in the public policies which favor access to information and to choice regarding the place to give birth.

\section{REFERENCES}

1. Feyer ISS, Monticelli M, Volkmer C, Búrigo RA. Publicações científicas brasileiras de enfermeiras obstétricas sobre o parto domiciliar: revisão sistemática de literatura. Texto Contexto Enferm [online]. 2013 Jan-Mar[acesso 2013 Nov 12]; 22(1). Disponível em: http://www.scielo.br/pdf/tce/ v22n1/pt_30.pdf

2. Lessa HF. A saúde da mulher e a opção pelo parto domiciliar planejado [tese]. Rio de Janeiro (RJ): Universidade Federal do Rio de Janeiro; 2012.

3. Ministério da Saúde (BR). Secretaria Municipal de Saúde e Defesa Civil do Rio De Janeiro. Indicadores de Saúde da cidade do Rio de Janeiro. Brasília (DF): MS; 2010.

4. Jonge A, Goes VD, Ravelli AC, Amelink-verburg MP. Mol BW, Nijhuis JG, et al. Perinatal mortality and morbidity in a nationwide cohort of 529n688 low-risk planned home and hospital births. BJOG. 2009 Abr; 10(1):1-10.

5. Boucher D, Bennett C, MacFarlin B, Freeze R. Staying home to give birth: why women in the United States choose home birth. J Midwifery Womens Health. 2009 Mar-Abr; 54(2):119-26.

6. Evers AC, Brouwers HA, Hukkelhoven CW, Nikkels PG, Boon J, Hillegersberg J, et al. A perinatal mortality and severe morbidity in low and high risk term pregnancies in the Netherlands: prospective cohort study. BMJ. 2010 Nov; 34(5639):1-8.

7. Birthplace in England Collaborative Group. Perinatal and maternal outcomes by planned place of birth for healthy women with low risk pregnancies: the birthplace in England national prospective cohort study. BMJ. 2011 Nov; 343(7400):1-13.

8. Victora CG, Aquino EML, Leal MC, Monteiro CA, Barros FC, Szwarcwald CL. Maternal and child health in Brazil: progress and challenges. Lancet. 2011 Mai; 377(9780):1863-76.

9. Ferreira ABH. Dicionário Aurélio de língua portuguesa. $5^{\mathrm{a}}$ ed. Rio de Janeiro (RJ): Editora Positivo; 2011.

10. Spoel, P. A feminist rhetoric on informed choice in midwifery. Rhetor [online] 2007. [acesso 2010 Abr 20]; (2):1-25. Disponível em: http://uregina. ca/ rheaults/rhetor/2007/spoel.pdf

11. Malheiros PM, Alves VH, Rangel TSA, Vargens OMC. Parto e nascimento: saberes e práticas humanizadas. Texto Contexto Enferm. 2012 AbrJun; 21(2):329-37.

12. Hammersley M, Atkinson P. Ethnography: principles and practice. $3^{\mathrm{a}}$ ed. London (UK): Tavistock Publications; 2007.

13. Minayo MCS. Pesquisa social: teoria, método e criatividade. $28^{\mathrm{a}}$ ed. Rio de Janeiro (RJ): Vozes; 2010.

14. Campbell ML, Gregor FM. Mapping social relations: a primer in doing institutional ethnography. Oxford (UK): Altamira Press; 2004.

15. Campbell ML. Dorothy Smith and knowing the world we live in. J Soc Social Welfare [online]. 2003 [acesso 2010 Abr 20]; 30(1): Disponível em: http://www.thefreelibrary. com / Dorothy + Smith + and + knowing + the+world+we+live+in.-a099018712

16. Smith DE. Institutional ethnography: a sociology for people. Toronto (CA): Altamira Press; 2005.

17. Colacioppo PM, Kiffman M, Riesco MLG, Schneck C, Osava R. Parto domiciliar planejado: resultados maternos e neonatais. Rev Enferm Ref. 2010 Dez; Série III (2):81-90.

18. Smith DE. Institutional ethnography as practice. Lanham (US): Rowman \& Littlefield Publishers; 2006.

19. Diniz SG, Bick D, Bastos MH, Riesco ML. Empowering women in Brazil. Lancet. 2011 Nov; 370(9599):1596-8.

20. Rattner D. Humanização na atenção a nascimentos e partos: ponderações sobre políticas públicas. Interf Comun Saúde Educ. 2009; 13(suppl1):759-68.

21. Garbin HBR, Neto AFP, Guilam MCR. A internet, o paciente expert e a prática médica: uma análise bibliográfica. Interface Comun Saúde Educ. 2008; 12(26):579-88.

22. Gomes, ML. A prática obstétrica da enfermeira no parto institucionalizado: uma possibilidade de conhecimento emancipatório [tese]. Rio de Janeiro (RJ): Universidade Federal do Rio de Janeiro; 2012. 